\title{
Analysis of the Impact of Governance on Bank Performance: Case of Commercial Tunisian Banks
}

\author{
Chenini Hajer ${ }^{1}$ - Jarboui Anis ${ }^{1}$
}

Received: 19 October 2015 / Accepted: 8 March 2016/

Published online: 11 April 2016

(C) The Author(s) 2016. This article is published with open access at Springerlink.com

\begin{abstract}
Most studies that have investigated the relationship between governance and performance of banks were interested in the developed countries and to a lesser extent, the emerging countries. In this study, we tried to look from an empirical perspective, at the impact of governance through some internal mechanisms, on the performance of banks in a developing country like Tunisia. According to Kolsi and Ghorbel (2011), the effect of governance on the financial and stock market performance is still unknown. This result goes in the same direction as that of Adjaoud et al. (journal compilation 15, 2007), leading to the lack of connection between governance and traditional performance measures. The empirical analysis is performed on a sample of eight Tunisian commercial banks listed on the Stock Exchange over the period 2000-2011; we can conclude that there is no standard governance structure and that each bank should adopt the appropriate governance structure to improve the performance of the financial market, in general, and the banking market, in particular. The verification of this central assumption in the Tunisian context, therefore, is the fundamental contribution of this study. It is for this reason that the results we, even modest, have achieved allow enriching the issue of the impact of some governance variables varying according to the chosen performance measurement, which is a neglected theme in the Tunisian context.
\end{abstract}

Keywords Performance banks · Governance banks · Efficiency · Governance mechanisms · Data envelopment analysis (DEA) - Board of directors · Ownership structure

Chenini Hajer

hajer_chenini@yahoo.com

Jarboui Anis

anisjarboui@yahoo.fr

1 Laboratoire de Recherche en Technologie d'Information, Gouvernance et Entrepreneuriat «LARTIGE», Faculty of Economics and Management, University of Sfax, Street of Airport, km 4.5, LP 1088, Sfax 3018, Tunisia 


\section{Introduction}

The appearance of the theme of governance is assigned to the debate opened by Berle and Means (1932) who were executed after the 1929 crisis. The problem of governance for these two authors was born from the division of the property function into two functions: an adjudicative one and a control one. This quarter, due to a failure of the control systems which are responsible for key management discipline, would have caused deterioration in the performance and counting of shareholders. The problem of governance is thus part of a mind control officers.

In this due, financial institutions, mainly banks, are especially concerned with corporate governance. In fact, banks are characterized by distinct agency problems and are relatively supported as other nonregulated businesses. These agency problems are created mainly by the asymmetry of existing information between all stakeholders in the banking sector.

Previous researches are multiplied to give the determinants of an effective governance system. André and Schiehll (2004) argue that the literature reveals an association between the governance systems and business performance, but empirical research on this association did not provide conclusive results. In short, the different results show that the impact of governance mechanisms on performance remains an empirical question to explore. The ambiguity, both theoretical and empirical, prompted us to clarify this association for the Tunisian case.

Thus, our problem is to what extent the governance is important in achieving performance for banks in a developing country like Tunisia. The structure of this article is as follows: the first part provides a brief overview on bank performance and the measurement methods. The second part presents a descriptive analysis of bank governance. Finally, in the third part, we test the existence of a relationship between bank governance and performance.

\section{Literature Review}

\section{Bank Performance}

\section{The Concept of Banking Performance}

In general, the performance is defined as the achievement of the objectives set forth by the firm (the bank) within the agreed time and with minimal costs while using the available resources.

For example, for a manager, the performance may be profitability or competitiveness for the company or for the employee, the work environment, or the quality of services rendered for the customer. The multiplicity of possible approaches brought out a concept determined due to the diversity of groups that make up the organization.

\section{Measurement of Bank Performance}

The measure of performance is, as any function of control and management, a way to guide the behavior of the actors of an organization and motivate them. There fare, 
improvement cannot take place unless there is a way to get feedback on performance, because measure is the first step to improvement.

There are two basic types of measurement of bank performance. The first type is related to the results (the second one financial measure) focuses on the determinants of the results (nonfinancial measures) such as quality, flexibility, use of resources, and innovation. This stipulates that, as part of performance, measurement can be established around the concepts of outcomes and determinants.

In fact, we notice that there is an evolution of performance models on financial measures. Therefore, many studies have used criteria such as profitability ratios (return on assets (ROA); return on equity (ROE)) and cost-efficiency for measuring bank performance.

Profitability Ratios as a Measure of Bank Performance Several authors used the ROA and ROE measurement to designate corporate financial performance.

Return on Assets This variable represents the rentability of funds employed and expresses the ability of these funds to create a certain level of operational benefits.

This measurement has been used by a large number of authors like Adams and Santos (2005) and Eisenberg et al. (1998).

The measurement, which will be kept throughout this study, for the calculation of ROA is as follows:

$$
\mathrm{ROA}=\text { net income } / \text { total assets }
$$

Return on Equity This ratio is also called the financial profitability coefficient. It is considered among the most financial indicators used to measure banking performance. It shows the contribution of equity in the realization of the result. It measures, in some way, the investor's returns level, that is, the higher it is, the more the funds allocated are more effectively used to achieve a positive result. Several authors have used, too, this performance measure as Bouri and Bouaziz (2007).

The measure that holds to measure the ROE is as follows:

$$
\mathrm{ROE}=\text { net income/equity }
$$

Efficiency as a Measurement Tool of Bank Performance Johonsen and Scholes (1997) define efficiency as an internal measurement of business performance; it is frequently assessed in terms of cost, production, profit, or productivity, and it is measured by the amount of resources used to produce a unit of goods or services.

In other words, efficiency is the ability to use the minimum possible of resources to achieve a given level of efficiency. It measures the absence of waste in the use of resources.

Thus, efficiency measures the productive performance of banks and not only their financial performance.

However, effectiveness is the nature of what is effective. It is the ability to achieve the desired or expected result to achieve the objective. Goals can be broken down into one or more criteria: time, quantities, costs, quality, profitability, etc. 
Effectiveness is also the quality of a person performing a task effectively, which achieved the objectives set for it. In business, effectiveness is one of the evaluation criteria of an employee by his manager.

In their journals, microeconomic studies seeking to measure the efficiency of the banking sector, Berger and Humphrey (1997) identify five main different techniques: two nonparametric approaches, the method of data envelopment analysis (DEA) and the free disposal hull (FDH), and three parametric approaches, namely the stochastic frontier approach (SFA), the approach of free distribution (DFA), and the thick frontier approach (TFA). Of these five techniques, those of stochastic frontier and data envelopment are mostly used. We will outline two approaches that are the method of DEA, which is the mostly used.

*Data envelopment analysis (DEA) The first method of this group is a technique called linear programming DEA. For this method, the efficient frontier is estimated by a convex polyhedron enveloping all the observations, the most effective of which are on the border.

This linear programming was first introduced in the study of the efficiency described in the work of Charnes et al. (1978) which is based on the work of Farrel (1957). Banker et al. (1984) show that the measurement of efficiency, described in the work of Charnes et al. (1978), can be divided into two components: technical efficiency and scale efficiency.

The method DEA has in recent years a great success through its use, especially after the development and changes in the level of this technique by Seiford and Thrall (1990) and Miller and Noulas (1996), and more recently by Alam (2001).

\section{Presentation of the Tunisian Banking System}

The Tunisian banking system currently has about 30 banks organized around the Central Bank of Tunisia. It comprises four categories of banks: deposits, development, sales, and offshore banks.

It can be concluded that the reforms introduced in 1986 guided the Tunisian economy toward liberalization through deregulation and improved functioning of the financial market.

Given the sensitivity of the sector in question and its key role in placing the heart of any economic restructuring of the banking system has become a priority for Tunisian economic and monetary authorities.

\section{Banking Governance}

However, to study the governance of banks in a relevant way, fake it back to their characteristics. Indeed, banks are more opaque than other firms. The asymmetry of information is everywhere. It affects the relations between the leaders and members of the bank's board. It also affects the relationships of internal and shareholders. Therefore, banks are highly regulated as other firms.

The etymological meaning of the term "governance" is oriented on how quotas are governed. The historical evolution of the term and its theoretical approaches led to a proliferation of definitions and has concluded that the plurality and diversity of meanings reflects the sensitivity of the concept of governance. 
It is noteworthy that thoughts currents have used the notion of governance with different purposes, and it is possible to identify the common elements which refer to different thoughts when using the term. In other words, this serves aims to clarify and determine the characteristics and modalities of governance.

However, before addressing the governance mechanisms, it is important to rely on the study of the movement of "corporate governance" in Anglo-Saxon countries and in France and try to distinguish the different system governance therein.

\section{Corporate Governance Systems}

For most theorists, there are two main models of governance: governance models, which focus on the functioning of markets, and models that are based on strong involvement of banks and limitation of market mechanisms. In addition, there are systems that borrow median each of the two streams.

*Bank-oriented systems or Germano-Nippon Model

The governance system is said to be a network if the control is provided by a bank that is both creditor and main shareholder of the company and also by the firm's partners.

It was particularly Germany and Japan, which have favored the emergence of a strong banking sector, through the concept of universal banking, which can help companies finance them. This system also obeys internal mechanisms that provide good preventive capacity and facilitate cooperation and long-term investment when their healing ability is limited.

*Oriented systems markets or the Anglo-Saxon model

The system is said to be market if the control and regulation will operate through the financial market through takeovers.

The Anglo-Saxon model encompasses the USA and Canada which presents governance similarities. It is characterized by dispersion of share ownership, separation of ownership, and management and emphasis on financial markets.

*The French model or hybrid system

There are hybrid or median governance systems between market systems and network systems. These are the Italian and French cases. This model is characterized by government intervention to shape the governance system. Otherwise, the governance system is said hybrid if the control operates both through market and financial institutions.

\section{The Basic Theories of Governance}

The concept of governance has evolved through the theoretical literature. Indeed, a review of research, both theoretical and empirical, reveals the existence of two main streams that offer different explanations of the effectiveness of organizations and their existence. The first is related to contract and the second cognitive origin.

The Contractual Theories of Governance The shareholder approach

In this approach, the firm is seen as a nexus of contracts, to manage centrally all contracts necessary for production. In this perspective, the role of the firm is reduced to the resolution of conflicts of interest. Three theories are the essence of this contractual power figure out: the theory of property rights (Alchian and Demestz 1972), the agency theory (Jensen and Meckling 1976), and the theory transaction costs (Williamson 1985). 
*The theory of property rights

Alchian and Demestz (1972) are the founders of this theory. Both founders consider the firm as a nexus of contracts, and the leader's mission is to define the nature of tasks and to choose the people who must execute within the "nexus" cooperative.

*The agency theory

Jensen and Meckling (1976), founders of the agency theory, inspired by the approach of Alchian and Demsetz, define the firm as a nexus of contracts. The explanatory model of financing and ownership structures is based on information asymmetry assumptions and conflicts of interest between the owner-manager, the new shareholders, and financial creditors. For Jensen and Meckling (1976), "there is an agency relationship when a person uses the services of another person in order to perform on his behalf any stain."

*The transaction cost theory

This theory was founded by Williamson (1985) that conceives the firm as an alternative way of organizing parallel market transactions. It considers that the firm exists to overcome market failures, problems related to asset specificity, and opportunism potential actors. Based on the principle of efficiency, Williamson defines transaction costs as "the costs of contractual trade in goods or services between companies."

The theory of rooting

In the late 80 s, the theory of rooting was developed by Morck et al. (1988). It challenged the foundations of contractual theories in general and the theory of the particular agency. This theory seems to provide an appropriate framework for analyzing opportunistic strategies of the leaders and their consequences on the control systems and on the company's performance. Rooting is for leaders to value (themselves) their presence within the company by making costly dismissal, and thus reducing their risk of replacement.

The partnership approach

If the shareholder approach favoring the study of conflicts between managers and shareholders, the recent evolution of contractual theories of the firm takes into account all the stakeholders. The partnership approach has its roots in the representation of the firm as a production team, in which value creation or organizational rents are due to synergies among the different factors of production.

Such an approach, proposed by Charreaux and Desbrières (1997), supposes that the relationship between the firm and the various stakeholders are not just shopping but are constructed to create value. This approach leads to studying the system of governance in its ability to create social value, equal to the difference between the sum of income valued at price opportunity and those of opportunity costs for different factors of production.

Cognitive Theories of Governance Contrary to contractual theories, which can be interpreted as extensions of the neoclassical economic model, these theories (evolutionary theory of the firm, theories of resources and skills, etc.) radically break with it.

Cognitive theories are based on a radically different view of the value creation process to the extent that they lead to giving central importance to building skills and capacity of firms to innovate, to create their investment opportunities, and change their environment. The contractual theories, giving an exclusive almost interest to conflict of interest, ownership of annuities, are silent productive dimension of value establishment. 
It is likely, however, that the main determinant of this creation lies not in the balancing of interests (disciplinary perspective) but is in the cognitive dimensions of value creation.

The firm also exceeds its disciplinary mission to take a more active way. In this sense, Charreaux notes that, according to cognitive theory, the firm is treated simultaneously at a nexus of contracts and a set of specialized knowledge.

This cognitive dimension of governance should not lead, however, to overlook the contractual approaches: the two dimensions are complementary and interlinked. Cognitive theories focus more on the development of human capital through the process of learning and innovation, while contractual approaches explain the dynamics of firm's governance system and its implications for the analysis of control problems and incitement.

\section{The Control Mechanisms and Resolution of Conflicts of Interest}

The usual restraint typology distinguishes internal and external mechanisms of a firm. The hierarchy of these different mechanisms is, however, not universal and may change depending on the type of organization, and their contents may vary according to the authors.

External Control Mechanisms and Bank Performance The market of goods and services

The market of goods and services should encourage good management. It can be the cause of perverse effects by encouraging leaders to assume a high level of risk in the investment choices in order to obtain comparable profits of competitors. During this, the discipline exerted by the market of goods and services is often inefficient. Indeed, Jensen (1993) posits that "when the market discipline of goods and services takes decision, it is often too late to save the company."

The legal and regulatory environment

The legal framework can be a means of control by requiring manager's constraints forcing them to make more cautions in spending on benefits of this kind. However, the effectiveness of this mechanism seems limited. Indeed, leaders often find ways to circumvent certain regulations.

The labor market

The labor market plays an important role in resolving the conflict between shareholders and managers. This market is responsible for assessing the value of constant managers. The goal of this model is to make a market wage revision executives so that the process solves the incentive problems that can achieve endogenous processes in a situation where there is separation of ownership and control.

The financial market

The financial market plays a crucial role in regulating the conflicts between the shareholder and the officer since it allows sanctioning incompetence and opportunism of the leaders who do not maximize the value of the firm.

This mechanism appears effective, even though without limits. Indeed, several criticisms have been addressed to takeover market as a means of discipline leaders, and some studies show that the profitability, productivity, and firms' market share that 
undergone takeovers are often better than those of firms located in the same area and that they remain independent.

Internal Mechanisms Bank's governance is characterized by internal mechanisms firms, the aim to influence and monitor the behavior of the leader. Indeed, the effectiveness of internal system of bank's governance through those of its main elements the board and ownership structure in the control of management and protection of interests of the bank in line with those of its various partners.

Board of directors

In general, the board is considered one of the main instruments to address the shortcomings of managers (Adjaoud et al. 2007). Thus, Hermalin and Weisbach (2003) describe him as "the heart of governance."

Several factors combine to have a good composition of the Board of Directors (the presence of independent outside directors, duality, board size, the presence of specialized committees, etc.). The composition of the board was the subject of several studies and debates. In an environment characterized by very rapid change, the challenge of any board is to go beyond its traditional role and strengthen its oversight role. It is therefore to improve board independence, composition, transparency, accountability to shareholders and other stakeholders, and meeting frequency (Louizi 2007).

Indeed, the size of the board can also have an impact on risk-taking by the manager. Adams and Mahran (2003) indicated that when the size of Board of Directors is high, firms still have high performance levels associated with high levels of risk. They also found that when it comes to a board whose size is reduced, its members can be easily manipulated and influenced by the leader, while Jensen suggests a relatively small board (comprising seven to eight members) to be more effective and can be controlled by the executive.

The ownership structure

The concentration of ownership is considered an internal governance mechanism in the governance literature. The ownership structure, whether owned by the family or the state, plays a role in governance.

In the governance banking system, the ownership structure also acquires great importance. Its effectiveness depends on the nature of shareholders, objectives, and scope of their disciplinary actions.

Lang and So (2002) argue that the ownership structure has no impact on the accounting performance and the shareholding of the state and that foreign investors has a negative impact on the market performance of commercial banks.

The duality of the leader

The "duality" can be defined as the appointment of the same person over the same period, the two positions of the Director General and the Chairman of the Board. Regarding the banking sector, few studies have addressed the effect of duality on the performance of banks. Pi and Timme (1993) find that efficiency and return on assets of banks are lower as part of duality.

Indeed, the combined functions of the Chairman of the Board and the Director General allows for increased knowledge of the activities and the bank's environment. The dual structure improves the competence and commitment of leaders to lead to greater efficiency of banks. They would be motivated to develop a good reputation in the labor market. Duality has significant costs that offset its potential benefits for most 
large firms. Indeed, the position of the president banks is extremely valuable to pursue a strategy of rooting and to enjoy its privileges. Paquerot (1997) explains that, in addition to full compensation, the position allows the officer to conclude more easily implicit contracts with partners. It has to that effect direct control over the assets and can be used to develop its human capital.

\section{Relations Between the Internal Governance System Elements}

It describes the board of directors and the ownership structure as an internal governance mechanism. In what follows, we will focus on the various relationships between them. In addition, with their various elements, they can accord the context of their application to be a substitute or complement.

Empirical studies considering the relationship between internal governance mechanisms, essentially the board of directors, ownership structure, and performance are very limited in terms of emerging countries in the case of banks (Arun and Turner 2004).

Therefore, they substituted the relationships between the elements of the ownership structure and those of the board. First, the shareholding by domestic administrators in small size tips replaces the presence of external ones. Hirschey (1999) notes that the increase in equity by internal library members implies a weakening of the need for outside directors to control the executive.

In this respect, the strong internal managerial ownership reduces the probability of having the dual management and control, by replacing the board. This is an empirical result confirmed by some studies such as Hermalin and Weisbach (2003) and Bathala and Rao (1995). Indeed, the board is often large when officers hold a significant share of capital and when it has external members (Spong et al. 1999). The presence of the latter is also substitutable for the concentration property. Thus, the actions taken by the majority shareholders to control the leaders are so strong and influential that the use of independent directors cost expensively. These actions also replace the revocation of threat made by the council to encourage leaders to maintain good performance. Several authors as Agrawal and Knoeber (1996) confirm the substitution relation concentration of ownership with the intensity of the control exercised by the board through its independence, its size, and the separation of management functions of the General and Chairman of the Board.

Nevertheless, in a bank characterized by the duality of its management, controlling shareholders can reduce their shareholdings. In doing so, managers centralize decisionmaking. Thus, there are alternative relationships between the presence of institutional investors and disciplinary authority of the board. Indeed, these powerful granny shareholders if they are not the majority tend to assume control of leaders. This reduces the potential involvement of the board with other members in this regard.

Furthermore, improved governance can be achieved through the existing complementarities between the internal mechanisms that work together to improve performance.

The ownership structure affects the composition of the board determined itself that executive compensation. Thus, the percentage of outside directors increases the participation of institutional investors and external capital. This is the assumption made by shareholder vote Whidbee (1997). 


\section{The Bank Governance}

Ownership Structure and Bank Performance Shipments of the bank's ownership structure during the 1990 and the beginning of 2000 have significantly altered the governance of banking institutions. Studies of US companies have typically used the term "governance" to refer to the methods used by shareholders in order to reduce managerial agency costs (Berger and Mester 2003). The governance studies that are interested in countries other than the USA, particularly developing countries, have often centralized on the role of the ownership structure in reducing these agency problems due the weak legal infrastructure. In more, it is well known that all shareholders adopt the goal of maximizing the value of the firm.

The ownership structure is an important governance mechanism because it is adapted in order to take into account the connection between ownership structure and performance in the context of agency theory and the public choice. The main problems/agent can occur when there is a separation between ownership and control.

Wide literature has focused on the relationship between governance and performance banks (Bonin et al. 2005; Williams and Nguyen 2005). Some assessed the static effects of different types of bank ownership structure, the effects of long-term performance associated with a domestic property, foreign, or public. On the other addressed the dynamic effects of changes in the ownership structure of the bank, the effects of performance related to domestic mergers and acquisitions, foreign acquisitions, or privatization. In some cases, these studies have also examined the effects of selection of some banks that have undergone dynamic changes in governance.

Impact of the Board on Banks Performance Added to the ownership structure discussed in the previous paragraph, there are also other internal mechanisms that influence bank performance: these mechanisms include mainly the board which, through its size and composition, will have an impact on banking performance.

Impact on the size of the board on banks performance

According to the agency theory, the large size of the board promotes its domination by the leader and eventually creates conflicts of interest between the directors and managers. This creates a fragmented inefficient board, with difficulties to reach a consensus on important decisions (Jensen 1993).

Some authors then conclude that board size is negatively related to the performance of firms (Hermalin and Weisbach 2003). However, several others stressed the positive effect of a large size. For these latter, the added ability to larger tips can be larger than the increase in communication problems, coordination, and decision-making.

Moreover, after studying 35 banks and bank holding companies in the USA from 1986 to 1999, Adams and Mahran (2003) show that those banks with large tips have higher performance than banks with small tip size. Furthermore, by examining the relationship between the size of the board and performance, Belkhir (2005) found, in contrast to theories that predict that smaller boards are more efficient. Instead, he found a positive relationship between the size of the board and bank performance. 
It is wise to check the results of these studies by the following hypothesis:

\section{H1: The board size has a positive impact on bank performance; the larger the} size is, the larger performance will be.

Impact of independent members on banks performance

*Impact of foreign directors on banks performance

Studies concerned with the governance of banks by foreigners such as Claessens et al. (2001) and Berger et al. (2000) often spot the differences in efficiency between banks with high foreign ownership and those with strong local private ownership. Indeed, the first banks, usually part of bank holding companies, benefit from economies of scale that characterize these large organizations. They also have the advantage of serving a customer base of multinational basis by moving to other countries mainly those harboring foreign subsidiaries of their clients (local companies). Moreover, banks with high foreign ownership have better access to capital markets, a greater ability to diversify risk, and greater opportunities to offer some of their services to foreign clients not easily accessible to local banks. In developing countries, foreign-owned banks from developed countries also have access to new technologies primarily in information. Bonin et al. (2005) argue that in developing countries, mainly those in transition (open economy, etc.), all these benefits outweigh possible drawbacks due to disparities in regulations and economic realities.

Besides, Oxelheim and Randy (2003) found that the impact of foreign directors on the performance of firms is positive. Their study covers more than 200 companies with seats in Sweden and Norway from 1996 to 1998; they argue that the recruitment of a new foreign member to the board of a firm is perceived by investors as a signal of transparency and willingness to improve governance. What gives them more confidence in activism and independence of the council and therefore increases the value of the firm. All these arguments allow assuming that

H2: The higher the proportion of foreign directors is, the more performing banks will be.

*Impact of representatives of the state and public institutions to the board on the performance of banks

Based on the assertions of agency theory, state-owned banks would suffer lower disciplinary effect from the financial market. This would encourage their leaders to follow their own interests at the expense of the interests of their institutions. Managers of private banks then suffer greater pressure of their environment and a more intense disciplining effect of the financial market. This significantly reduces the efficiency of these banks (Lang and So 2002). Similarly, La Porta et al. (2002) show that in all countries, mainly developing, the shareholding of the state in commercial banks is a common fact and a clear account of their inefficiencies. In fact, the most important questions relate to the state ownership of banks concerning the availability of loans and allocation of loan portfolio and especially efficiency. Such banks are experiencing a low efficiency and suffer a high rate of nonperforming loans. These issues overwhelm different goals of state-owned banks, which often engage in financing-specific sectors 
or regions, to provide direct export credits, operating in cooperation with other state institutions, etc. Other studies have focused on the governance of banks in emerging countries also stressed that the state or public institutions hold significant shares in their capital. Their findings tend to predict the negative effects of this property and the presence of representatives "state or government" to advise on the performance of banks. The following assumptions must be true:

\section{H3: The higher the percentage of directors representing is, the less performing} banks will be.

H4: The higher the percentage of directors representing public institutions increases, the less performing banks will be.

*Impact of the duality of management on banks performance

Duality means the appointment of the same person, over the same period, the two positions the Director General and the Chairman of the Board. Duality has significant costs that offset its potential benefits for most large firms. Indeed, the position of the president banks is extremely valuable to pursue a strategy of rooting and enjoy its privileges. Paquerot (1997) explains that in addition to full compensation, the position allows the officer to conclude more easily implicit contracts with partners. It has for this purpose a direct control over the assets and can use to enhance its human capital. The president can also increase its informational advantage on the board and strengthening of employment security.

In addition, few studies have examined the effect of duality on the performance of banks. Pi and Timme (1993) show that in the case of the management of duality, efficiency and performance of the bank's assets is lower. They find in their investigation on big Americans commercial banks during the years 1988-1990, conflicts with the duality of principal / agent may be exacerbated due to the consolidation of the monitoring process and the decision, which negatively affect the bank's performance. The contrary, the influence is positive in the case of the separation between functions of decision and controls the main conflict/agent does not seem to existing strengths.

So, duality can significantly increase the power of the executive in the bank's board in accordance with Gary and Gleason (1999). Their study focused on the relationship between the probability of financial distress and bank governance variables. They find that it is the only variable that has significant effects, namely reduction of the probability of financial distress. The explanation lies in the fact that the leader who is also the chairman always wants to protect his powerful position and makes decisions that involve less risk.

By cons, Griffith and Fogelberg (2000) do not notice any impact of duality on the performance of banks. They explain that the granting of an additional title to the leader does not necessarily allow him to affect the bank's performance. It is rather the level of ownership that matters. They note in addition that control done by the chairman of the board generally has a low impact on the delivery of the General Manager. 
Finally, the duality can positively influence the performance under certain conditions (high dynamic sector) and negative in other circumstances (munificence sector high). This assumes that

\section{H5: Duality has a negative impact on the bank performance.}

The impact of governance on the bank performance

*Governance variables

-The variable of the leadership duality (DUAL)

Duality is defined as the appointment of the same person, over the same period, to both posts of the Director General and the Chairman of the Board. According to Jensen (1993), this variable has a negative effect on the value of the corporate market.

According to Mejdoub (2008), the separation of the functions of chairman and the Director General reduces agency costs and improves performance.

Note also that another group of authors such as Daily and Dalton (1992) and Brickley et al. (1997) confirm the absence of any effect envisaged accumulated principal and manager functions Chairman of the Board on the value of the firm. On the other hand, Pi and Timme (1993) show that with the duality, efficiency, and banks' asset returns are lower and that the main conflict agent may be exacerbated due to the consolidation of the monitoring process and decision.

- The variable of the board size (TAILC)

It is the total number of directors that serve on the board. According to the agency theory, the board size is a source of conflict intensification between the managers and administrators and of the leader's dominance, which leads to a fragmented and ineffective board.

The size of the board is also considered as a variable that can have a significant effect on its efficiency (André and Schiehll 2004). The results of Yermack (1996) and Bhagat and Black (2002) show the size of the board has a negative effect when the board loses its effectiveness when it grows. Contrary to these results, those of Godard (2001) show the absence of the effect of the size of the board on the performance of French companies, regardless of the performance measures used. Adams and Mahran (2003) state that banks that have a large board show a higher performance than those whose board is reduced.

- The variable of the percentage of foreign directors (ADMETR)

This variable shows the percentage of foreign directors who serve on the board. It is measured by the ratio of the number of foreign directors to the total number of directors. According to Leightner and Lovell (1998), banks' openness to foreign capital in emerging countries improves their performance by granting them greater access to technology and mainly to the best governance practices. Besides, Oxelheim and Randy (2003) found that the impact of foreign directors on the firms' performance is positive.

Indeed, banks with high foreign ownership have better access to capital markets, a greater ability to diversify risk, and greater opportunities to offer some of their services to foreign clients not easily accessible to local banks.

- The variable of the percentage of directors representing the government

This variable is measured as the ratio of the number of directors representing the government to the total number of directors. Based on the hypotheses of the agency 
theory, state-owned banks would be subject to a less disciplinary effect by the financial market. This would encourage their leaders to follow their own interests at the expense of the interests of their institutions. Private banks are under intense pressure from their environment; therefore, this can reduce the inefficiency of these banks. La Porta et al. (2002) show that in countries, mainly developing, the state's shareholding in commercial banks is a common fact and because of their inefficiencies.

- The variable of the percentage of directors representing the public institutions (ADMETAP)

This variable is measured as the ratio of the number of directors representing the public institutions to the total number of directors. The several studies that focused on the bank governance in emerging countries were carried out by Koh and Soon (2004) who emphasized that public institutions hold large stakes in their capital. Their results predict that this property and the presence of representatives on the boards have negative effects on banking performance.

- The variable of the bank size (ACTIVE)

The bank size is measured in two ways, either through the natural logarithm of the business figure or the ratio of assets to sales. This variable is also used by Godard (2001)who found that the bank size has a positive and significant effect on profitability suggesting the existence of economies of scale. Other authors such as Adams and Mahran (2003) also found that performance is positively associated with the bank's size. Based on these results, it is assumed in this study that the bank's size positively influences its performance.

\section{Regression Results and Discussions}

The efficiency measurement of a bank's ability to make the best use of its resources is to achieve the best possible performance. Therefore, we will retain the economic definition which refers to the ratio output/input.

The choice of a model "preferred" to determine the extent of the banking efficiency was not about agreement between the researchers saw that the actual level of bank efficiency is unknown. However, the specific characteristics of the Tunisian banking system can help to choose the most suitable technique with Tunisian commercial banks.

We will use the nonparametric approach outlined by Charnes et al. (1978) and more precisely the wrap method data (DEA) that meets the requirements of our study in terms of calculation of efficiencies in our sample scores.

\section{Implementation of the DEA Tunisian Commercial Banks}

\section{The Model Specification and Variable Selection}

Our empirical analysis deals with the calculation of the efficiency scores of Tunisian commercial banks for the period between 2000 and 2011. The sample used consists of eight deposit banks listed on the stock exchange, namely Amen Bank (AB), Arab Tunisian Bank (ATB), Arab International Bank of Tunisia (BIAT), National Agricultural Bank (BNA), Tunisian Bank (BT), Tunisian Banking Company (STB), International Banking Union (UIB), and Housing Bank (BH). 
Other commercial banks have not been considered because of the lack of information, and other categories of banks (development, sales, and off-shore) have not been selected because of their different activities, their smaller numbers, and the lack of data governance and clearer impact of external factors on them.

In addition, the retail bank group is the largest division in the financing of the Tunisian economy. So, the selected sample can then give an idea about the effects of governance on performance.

The financial data used are collected from the annual bank activity reports, annual reports of the Tunisian Professional Association of Banks, and guides the Tunisian stock exchange.

\section{Measure Variables}

The selection of inputs is challenging the power of the wrap method data (DEA) in the discrimination between banks. Indeed, each resource used by the bank is included as an input that will convert the resources to produce output.

The explanatory variables are the number of the staff, the capital, the total bank assets, equity, and net income.

The explained variables are ROA, ROE, and efficiency.

\section{Results}

The DEA method is applied to calculate the efficiency scores reflecting the good practice of the governance system. More specifically, the basic idea of the DEA method is the determination of a frontier that represents the best practice: the input that maximizes the output. The results reached after the application of the DEA, regarding the constant returns to scale by the DEAP 2.1 software, are shown in Table 1.

- Analyzing the efficiency score evolution per bank (2000-2011)

Table 1 shows the average technical efficiency of the Tunisian commercial banks during the observation period (2000-2011) which is $99.3 \%$. This brings us to the conclusion that technical inefficiency is $7 \%$ ( 1 to -0993). An average overall level of technical efficiency of $99.3 \%$ means that the sample studied is very efficient. Actually, an efficient bank has a combination of governance practices that will maximize performance and therefore makes it possible to minimize the agency costs.

On examining the Fig. 1 entitled the distribution of the efficiency scores presented above, we find that it means the nonefficiency of the bank structures. We can therefore conclude that the efficiency scores are highly concentrated between 0.993 and 0.998 .

From the Table 2 of the data descriptive analysis, we can see that

- Regarding governance variables, one notes that

- Fifty percent of the sample observations are banks where the president of the board is at the same time the chief executive officer, whereas in the remaining $50 \%$, there is a separation between the functions of manager and controller.

- The percentage of foreign directors on the board varies between 0 and $58 \%$, which is an average value of $20.7 \%$. 


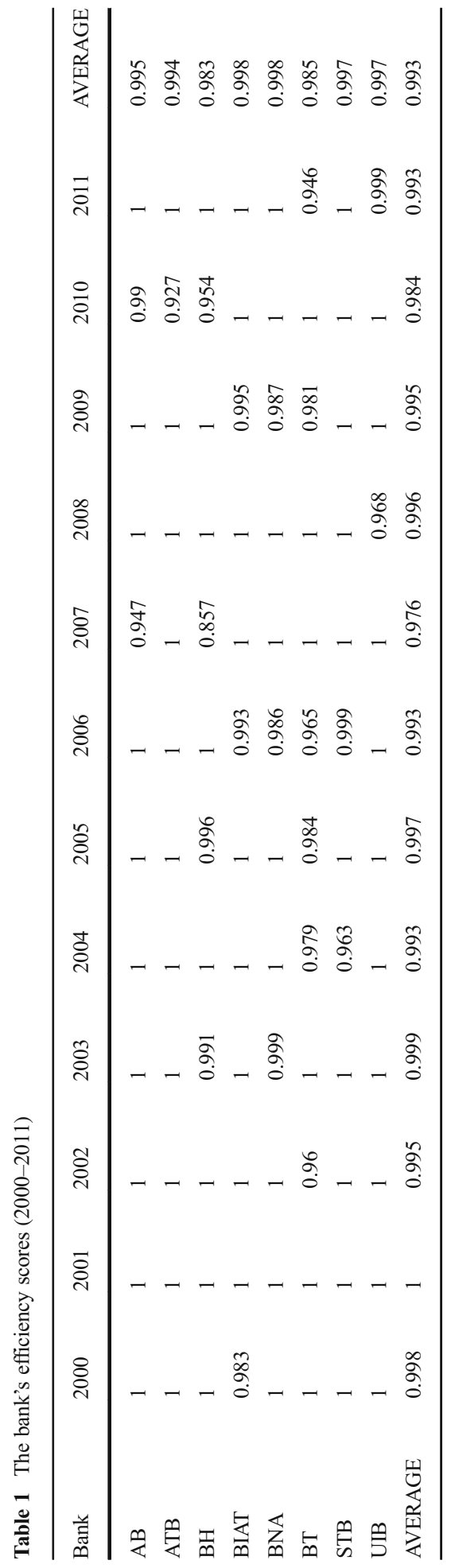




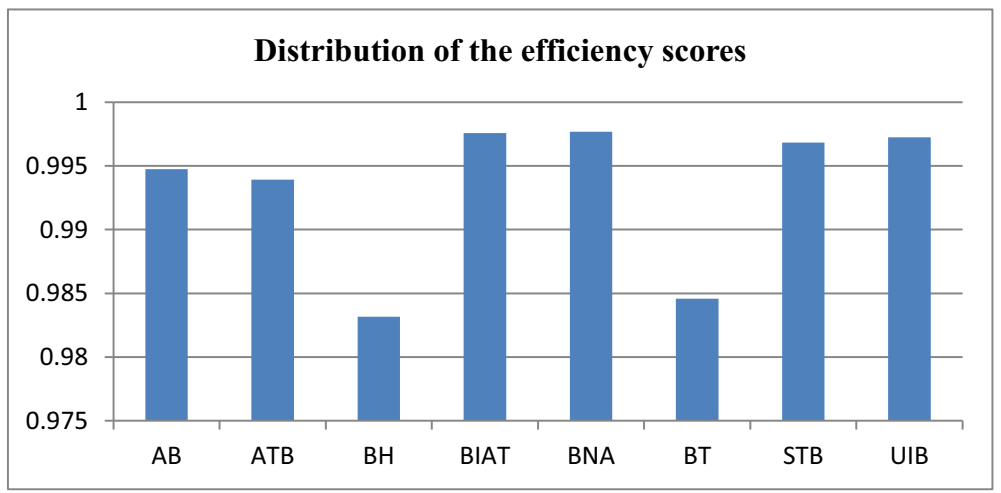

Fig. 1 Distribution of the efficiency scores

- The percentage of directors representing the government who serve on the board of directors is about $12.4 \%$ on average. However, this percentage varies between 0 and $72 \%$.

- The proportion of directors representing public institutions observed in banks is $16.3 \%$ on average. This share can reach $60 \%$ in public banks but no remains in private banks.

- The size of the board is between 7 and 12 with an average of $11.16 \%$ of the directors.

- In terms of performance variables, one notes that

- ROA: The average value of this ratio for the sample banks is $0.9 \%$ knowing that oscillates between a maximum of $0.32 \%$ and a minimum of $0 \%$.

- ROE: The average value of this ratio to average $9.4 \%$ knowing that oscillates between a maximum of $2.3 \%$ and a minimum of $0 \%$.

The Correlation Between Governance and Performance of the Tunisian Commercial Banks

Model Overview The regression model is the basis of econometrics. It consists of an equation linking an endogenous variable (to be explained) to a single exogenous one (predictor). It is written as follows:

$$
\mathrm{Y}_{\mathrm{it}}=\alpha_{0 \mathrm{i}}+\alpha_{1 \mathrm{i}} \mathrm{X}_{1 \mathrm{it}}+\alpha_{2 \mathrm{i}} \mathrm{X}_{2 \mathrm{it}}+\ldots+\alpha_{\mathrm{ki}} \mathrm{X}_{\mathrm{kit}}+\mu_{\mathrm{it}}
$$

where $i$ is the banking index and $t$ the time index.

Usually, a regression model involves three types of variables:

$X_{j i t}$ In our case, it is the performance explanatory variable which measures the different forms of governance within a bank. The variables are DUAL, TAILC, ADMETR, STATE, and ADMETAP LACTIF.

$Y_{i t} \quad$ It is a performance measure. In our case, it will be represented by the following ratios: ROA, ROE, or the technical efficiency score (ET). 
Table 2 Descriptive statistics of the variables

\begin{tabular}{llll}
\hline Variables & Average & Maximum & Minimum \\
\hline Combine the functions of CEO and Chairman of the Board of Directors & 0.5 & 1 & 0 \\
Size of the board & 11.167 & 12 & 7 \\
Percentage of foreign directors & 0.207 & 0.58 & 0 \\
Percentage directors representing the STATE & 0.124 & 0.72 & 0 \\
Percentage directors representing public institutions & 0.163 & 0.6 & 0 \\
Log (actif): size & 7.979 & 8.782 & 5.633 \\
ROA & 0.009 & 0.032 & 0 \\
ROE & 0.094 & 0.23 & 0 \\
\hline
\end{tabular}

The descriptive study was carried out on 72 observations

$\mu_{i t} \quad$ This variable expresses the random effect on the dependent variable which explains the other model factors that are made nonexplicit. It is the stochastic part of the model which makes it operational. The values of $\varepsilon_{i t}$, which are called theoretical disturbances or errors, are unobservable. One can only characterize them using a set of assumptions regarding their behavior.

Analysis of the Estimation Results Through the OLS Method Governance impact on banking performance measured by the ROA

The panel structure is perfectly homogeneous. We can therefore apply the ordinary least square method that allows a better adjustment which minimizes the sum of the residual squares. The first model adopts the ROA performance measure as the dependent variable.

The results of the ordinary least-squares (OLS) estimation are reported in Table 3.

$$
\begin{aligned}
\text { ROA }_{i t}= & \alpha_{0}+\alpha_{1} \text { DUAL }_{i t}+\alpha_{2} \text { TAILC }_{i t}+\alpha_{3} \text { ADMETR }_{i t}+\alpha_{4} \text { ETAT }_{i t} \\
& +\alpha_{5} \text { ADMETAP }_{i t}+\alpha_{6} \text { LACTI }_{i t}+\mu_{i t}
\end{aligned}
$$

Table 3 Results of the OLS estimates (governance/ROA)

\begin{tabular}{lc}
\hline Variables & ROA \\
\hline C & $0.014640(1.35)$ \\
DUAL & $0.013337(5.07)^{*}$ \\
TAILC & $-0.001150(-1.86)$ \\
ADMETR & $-0.002126(-0.52)$ \\
ETAT & $-0.016167(-4.72)^{*}$ \\
ADMETAP & $-0.025097(-5.56)^{*}$ \\
LACTIF & $0.000924(0.97)$ \\
\hline
\end{tabular}

The values in brackets are those of the t-statistics. $R^{2}=0.75 ;$ F-stat $=33.59(0.00)^{* *} ; \mathrm{DW}=0.68$

$*$, **The coefficient is significant at the 5 and $1 \%$, respectively 
Based on this result, we can conclude that the variable representing duality has a positive and significantly clear influence; therefore, H5 is rejected.

- Governance impact on banking performance measured by the ROE

The second model applies the ROE performance measure as a dependent variable. The regression results are reported in Table 4.

$$
\begin{aligned}
\text {ROE}_{i t}= & \alpha_{0}+\alpha_{1} \text { DUAL }_{i t}+\alpha_{2} \text { TAILC }_{i t}+\alpha_{3} \text { ADMETR }_{i t}+\alpha_{4} \text { ETAT }_{i t} \\
& +\alpha_{5} \text { ADMETAP }_{i t}+\alpha_{6} \text { LACTI }_{i t}+\mu_{i t}
\end{aligned}
$$

From this table, duality seems to have a positive and statistically significant impact on the return on equity.

- Impact of governance on banking performance measured by efficiency

The third model applies efficiency as a measure of performance. The EFF is a dependent variable. The regression results are reported in Table 5.

$$
\begin{aligned}
Y_{i t}= & \alpha_{0}+\alpha_{1} D U A L_{i t}+\alpha_{2} \text { TAILC }_{i t}+\alpha_{3} \text { ADMETR }_{i t}+\alpha_{4} \text { ETAT }_{i t}+\alpha_{5} \text { ADMETAP }_{i t} \\
& +\alpha_{6} \text { LACTI F }_{i t}+\mu_{i t}
\end{aligned}
$$

On the basis of the regression of governance variables on the $Y$ variable that measures the efficiency of banks, it can be noticed that all coefficients show that there is total nonsignificance for all the variables. Neither the adjustment quality nor Fisher's statistic gives a leverage to accept this model. This result makes us conclude that there is no relationship between the variables representing the characteristics of the governance form within banks and the level of their efficiencies. Indeed, in the case of the Tunisian commercial banks, efficiency does not depend on governance mechanisms.

Table 4 Estimation results through the OLS (governance/ROE)

\begin{tabular}{lc}
\hline Variables & ROE \\
\hline C & $0.146284(1.11)$ \\
DUAL & $0.036060(1.13)$ \\
TAILC & $-0.014528(-1.94)^{*}$ \\
ADMETR & $-0.014897(-0.30)$ \\
ETAT & $-0.102564(-2.47)^{*}$ \\
ADMETAP & $-0.060543(-1.10)$ \\
LACTIF & $0.014689(1.28)$ \\
\hline
\end{tabular}

$R^{2}=0.41 ;$ F-stat $=7.52(0.00)^{* *} ; \mathrm{DW}=0.49$

* indicate significance at the $5 \%$ levels

** indicates significant at the $1 \%$ level 
Table 5 Estimation results through the OLS method (governance/EFF)

\begin{tabular}{ll}
\hline Variables & EFF \\
\hline C & $1.039710(16.18)^{* *}$ \\
DUAL & $-0.016869(-0.00)$ \\
TAILC & $-0.000809(-0.22)$ \\
ADMETR & $-0.008643(-0.35)$ \\
ETAT & $0.029123(1.43)$ \\
ADMETAP & $0.002464(0.09)$ \\
LACTIF & $-0.004102(-0.73)$ \\
\hline
\end{tabular}

$\mathrm{R}^{2}=0.074 ; \mathrm{F}-\mathrm{stat}=0.87(0.00)^{* *} ; \mathrm{DW}=2.56$

\section{Analysis of the Estimation Results Using the Method of GLS}

Autocorrelation is one of the most common problems in the econometric analysis which concerns only the time series. The results of this test reveal that there is a problem of a positive autocorrelation, the thing which brings us to apply the methods of generalized least squares (GLS) to estimate the model.

The result for the three models is summarized in Table 6.

Based on the facts set out above, it can be concluded that the ASSET variable designating the bank size is the most significant variable with a negative sign for both forms of bank profitability (ROA and ROE). This result is consistent with those of

Table 6 Estimation results through the GLS method (governance/ROA, ROE, and EFF)

\begin{tabular}{llll}
\hline Variables & Performance & & \\
\cline { 2 - 3 } & ROA & ROE & EFF \\
\hline C & $0.0307^{* *}$ & 1.0397 & 1.043393 \\
DUAL & $0.0165^{*}$ & 0.4609 & -0.018403 \\
TAILC & $-6.06 \mathrm{E}-05$ & 0.0033 & -0.001123 \\
ADMETR & -0.0012 & -0.0233 & -0.007786 \\
ETAT & -0.0075 & 0.3651 & 0.032186 \\
ADMETAP & $-0.0346^{* *}$ & -0.0274 & 0.003551 \\
LACTIF & $-0.0022^{* *}$ & $-0.0192^{* * *}$ & -0.004192 \\
AR(1) & $0.8632^{* *}$ & $0.9947^{* *}$ & -0.212907 \\
$R^{2}$ & 0.903 & 0.848 & 0.115 \\
F-stat & 74.51 & $44.78^{* *}$ & 1.04 \\
DW & 1.85 & 2.24 & 2.19 \\
\hline
\end{tabular}

For the italic entries: We noticed an error autocorrelation problem signaled by a low value of the DurbinWatson for ROA and ROE in the result of the estimate by OLS. To correct this problem, made the transformation of the original model by introducing the error term as AR (1) and then made the re-estimation of the model by OLS. And the problem has been corrected to ROA and ROE

*, ** The t-statistics or Fisher are significant at the 5 and $1 \%$, respectively 
Boyd and Runkle (1993), Adams and Mahran (2003), and Godard (2001), who find the bank size has a positive and significant impact on profitability suggesting the existence of economies of scale. This result shows that the largest banks, in terms of total assets, are the public banks, namely the STB, BNA, and BH, which are recognized to be less efficient, in general.

\section{Discussions}

From the result in Table 3, it can be said the accumulated positions of the Director General and the Chairman of the Board in the case of Tunisian banks contribute in a remarkable way in performance (expressed in terms of economic profitability (ROA)). This contradicts the results of Mejdoub (2008) which shows that the duality can influence negatively on performance.

Next, the board size has a negative and insignificant impact; as a result, $\mathrm{H} 1$ is rejected. Therefore, the nonsignificance of this variable is explained by the fact that the size of board of the Tunisian banks is about the same. Actually, the number of directors who serve on the boards of the Tunisian banks is close to the maximum allowed by the law, that is, 12 members. This result is consistent with the results of Yermack (1996) and Bhagat and Black (2002), which show that this effect is negative since the board loses its effectiveness when it grows.

Similarly, foreign directors, who are individual outside members of the board with a high experience and good reputation, are asked to enrich bank governance. Despite this, the regression of their percentage on the ROA reveals a negative but no significant impact; therefore, $\mathrm{H} 2$ is accepted. This can be explained by the fact that these individuals generally ignore the Tunisian economic reality and may have difficulties in implementing their concepts of governance on the specific case of the Tunisian commercial banks.

The second and third significant variables in this model are ADMETAP and STATE. Actually, the coefficients associated with these two variables are negative and significant. We can confirm the agency theory, that is, state-owned banks would be subject to a lesser disciplinary effect from the financial market, which will drive their leaders to follow their own interests at the expense of those of their institutions. However, private banks would then be subject to more pressure from their environment and a more intense disciplinary effect from the financial market. These results comply with those generated by La Porta et al. (2002) who state that, in developing countries, the state shareholding in commercial banks is a common fact and a clear cause of their inefficiencies. Finally, the bank size is positively but not significantly correlated with the ROA. As consequence, the larger the bank is, the weaker its performance will be.

However, we can notice that, despite the favorable $\left(R^{2}\right)$ quality adjustment and the (Fstat) overall significance, the model faces a major error autocorrelation problem. In fact, this problem may challenge the results of the OLS estimation. It is therefore necessary to correct this by adding an autocorrelation and AR (1) term to the previous regression. This method is called GLS method, which will be applied in the following paragraph.

The result from Table 4 confirms the literature denouncing this form of leadership for power abuse by the executive. Jensen (1983) state that this combination of features raises the agency costs (impartiality of control, ambiguity of responsibilities, conflicts of interest, imbalance power, information asymmetry, etc.) and weakens the board effectiveness and therefore reduces performance. 
Next, the results reveal the existence of a significant negative correlation between the board size and performance measured by the ROE. According to the results of Hermalin and Weisbach (2003), the board size is negatively related to banking performance.

Moreover, we notice that the percentage of foreign directors and that of directors representing public institutions have a negative and insignificant impact. However, the presence of the state as a board member has a negative and significant impact. These results may support the same interpretations mentioned above. Finally, the bank size has positive but insignificant impact on its accounting performance measured by ROE.

We present the interpretations for Table 6 followed by built models regarding the variable regression and governance as well as by variables of the performance measurements of the Tunisian banks. First of all, regarding the governance variable regression on the measurement variable of the ROA performance, we notice that the dual variable has a positive and significant impact, which contradicts the results of Pi and Timme (1993). This result can be explained by the fact that the practice regarding the same person acting as both Chairman of the Board and the Director General board helps increase the knowledge about the activities and the internal and external environment of the bank.

Next, the variables representing the proportion of foreign administrators, the state, and the size of the board show a nonsignificant correlation. Finally, the variable size of the bank and the percentage of the administrators representing the public institutions have a negative and significant impact. Regarding the first variable, we can say that the smaller the bank is, the better its performance will be. Boyd and Runkle (1993) concluded the same thing by stating that due to the introduction of deposit insurance systems, the leaders can engage in high-risk activities in order to raise their earnings while increasing the bank's size. However, the performance may decrease with the increase of bad debts and potential losses. Regarding the second variable, we can say that the presence of these directors is closely related to their institutions' contribution to the bank's capital.

However, the results of the regression variables characterizing the bank governance mode in the Tunisian commercial banks on the ROE show that all the variables have a nonsignificant correlation excepting the bank's size variable which has a negative and statistically significant impact. The result of the bank's size variable can support the above interpretations.

Finally, the third model does not seem significant $\left(R^{2}=0.1151\right)$. In fact, no variable is significant. This result is consistent with the one found in the OLS model estimation. It can be concluded that these variables do not affect the bank efficiency.

\section{Conclusion}

The literature relating to the banking industry argues that the regulatory and institutional factors such as regulation, quality of the environment, market structure, or market discipline themselves as being key determinants of bank performance. These determinants can be extended to other factors, namely bank governance. That is why we looked at a database in order to provide evidence on the influence of this determinant of the performance of Tunisian commercial banks. That is why we looked at a database in order to provide evidence on the influence of this determinant of the performance of Tunisian commercial banks. 
To do this, we used the following methodology of analyzing the effect of governance on bank performance by performing first, a presentation of the different banking performance measures, namely the respective ratios ROA, ROE, and efficiency was determined by applying a nonparametric method called DEA.

The goal of this method is to determine the banks' efficiency scores during the study period. In second place, we estimated the model parameters.

The analysis of the impact of bank governance performance on the entire sample, we found that on one hand the size of the board, the presence of foreign directors, and the size of the bank had an insignificant impact on the level of performance. Moreover, the direction of duality, the presence of directors representing institutions, and state officials tend to increase the performance measured by economic profitability (ROA).

There is no significant relative relationship between performance and representatives of public institutions, foreign, duality management, and the bank's size. However, this relationship is significantly with the size of the board and representatives of the state. Similarly, the correlation between the variable efficiency, as an internal measure of bank performance, concluded the lack of a significant impact of governance variables.

It shows that the impact of governance on the performance of Tunisian commercial banks present divergent results. This discrepancy is linked to several characteristics of these banks other than their size, the size of their boards, the percentage of foreign directors, representatives of state and public institutions, and the duality of their directions and especially to other mechanisms in particular governance of the ownership structure. This course much influenced the composition, but this relationship of substitution and complementarities with the composition of the board in connection with their respective influences on bank performance.

The study of the impact of mode of governance on market values and the accounting performance of banks does not show unanimity in the conclusions. The impact of each governance variable varies according to the measure of the selected performance.

Finally, note this study was done on only eight commercial banks. This limit was imposed in part by the lack of data available for the other categories of banks. Moreover, it is dictated by the fact that the banks in our sample used are the most exposed to problems of governance that the presence of the relationship between ownership and control that characterized them.

The majority of Tunisian bank component production base are indeed a midsize banks and other hand are characterized by a high opacity. The establishment of an alternative market can be an incentive to adopt a policy that favors greater transparency and more generally to adopt good governance practices. Indeed, despite its comprehensiveness, the selected sample includes only eight banks. The sample narrowness will certainly affect the validity of some of our results. The number of banks has been retained in reality conditioned by data availability.

As for the variables, we limited ourselves to measurements of ratios ROA, ROE, and efficiency as indicators of banking performance. We have reproduced in this sense, the choice of existing variables in all of the most recent empirical studies of our research topic. Obviously, taking into account other governance variables and performance measurement such as the independence of directors and the presence of major shareholders in the board may make other answers to the issues raised and can enlighten advantage of the specificities of banking governance in Tunisia. It is, therefore, an earlier search path. 
Another avenue of research can be raised. This is to study the impact of all mechanisms of both internal and external efficiency of the bank.

Open Access This article is distributed under the terms of the Creative Commons Attribution 4.0 International License (http://creativecommons.org/licenses/by/4.0/), which permits unrestricted use, distribution, and reproduction in any medium, provided you give appropriate credit to the original author(s) and the source, provide a link to the Creative Commons license, and indicate if changes were made.

\section{References}

Adams, R. \& Mahran, H. (2003). Board structure, banking firm performance and the Bank Holding Company organizational form. Fediral Reserve Bank of Chicago Proceedings, Issue May, 408-422.

Adams, R. B., \& Santos, J. A. C. (2005). Identifying the effect of managerial control on firm performance ». Finance Working Paper, 101, 25.

Adjaoud, F., Zeghal, D., \& Andaleeb, S. (2007). The effect of board's quality on performance: a study of Canadian firms. Journal compilation, 15(4).

Agrawal, A., \& Knoeber, C. (1996). Firm performance and mechanisms to control agency problems between managers and shareholders. Journal of Financial and Quantitative Analysis, 31(3), 377-397.

Alam, I. M. S. (2001) A non parametric approach for assessing productivity dynamics of large U.S. Banks. Journal of Money, Credit and Banking, 33(1), 121-139.

Alchian, A. A., \& Demestz, H. (1972). Production, information costs and economic organisation. The American Economic Review, 62, 777-795.

André, P., \& Schiehll, E. (2004). Systèmes de gouvernance, actionnaires dominants et performance future des entreprises. Finance Contrôle Stratégie, 7, 165-193.

Arun, T., \& Turner, J. (2004). Corporate governance of banks in developing economies: concepts and issues. Corporate Governance: An International Review, 12(3), 371-377.

Banker, R. D., Charnes, A., \& Cooper, W. W. (1984). Some models for estimating technical and scale inefficiencies in data envelopment analysis. Management Science, 30(9), 1078-1092.

Bathala, C., \& Rao, R. (1995). The determinants of board composition: an agency perspective. Managerial and Decision Economics, 19, 59-69.

Belkhir M. (2005). Board structure, ownership structure and firm performance: evidence from banking. Working paper of University of Orléans.

Berger, A. \& Humphrey, D. (1997). Efficiency of Financial institutions: international survey and direction for future research. European Journal of Operational Research. 175-212.

Berger, A. N., \& Mester, L. J. (2003). Explaining the dramatic changes in performance of U.S. banks: technological change, deregulation, and dynamic changes in competition. Journal of Financial Intermediation, 12, 57-95.

Berger, A. N., DeYoung, R., Genay, H., \& Udell, G. F. (2000). The globalization of financial institutions: evidence from cross-border banking performance. Brookings-Wharton Papers on Financial Services, 3, 23-158.

Berle, A. A., \& Means, G. C. (1932). The modem corporation and private property (2nd ed.). New York: Harcourt, Brace and World. 1967. ISBN 0-88738-887-6.

Bonin, J. P., Hasan, I., \& Watchel, P. (2005). Bank performance, efficiency and ownership in transition countries. Journal of Banking \& Finance, 29, 31-54.

Bouri, A., Bouaziz, W. (2007). Indices de gouvernance actionnariale contre indices de gouvernance partenariale : application aux banques tunisiennes cotées. 4th International Finance Conference Investissement \& Financement : immatériel, TIC et valeur. 15-17 Mars 2007, Yasmine-Hammamet, Diar el Medina, Tunisie.

Boyd, J., \& Runkle, D. (1993). Size and performance of banking firms. Journal of Monetary Economics, 31, $47-67$.

Bhagat, S., \& Black, B. (2002). The non-correlation between board independence and long-term performance. Journal of Corporation Law, 27(2), 231-243.

Brickley, J. A., Coles, J. L., \& Jarrell, G. (1997). Leadership structure: separating the CEO and chairman of the board. Journal of Corporate Finance 3, 189-220.

Charnes, A., Cooper, W. W., \& Rhodes, E. (1978). Measuring the efficiency of decision making units. European Journal of Operational Research, 2(5), 429-444. 
Charreaux \& Desbrière (1997). Le point sur le gouvernement des entreprises. in Le G E. Paris Economica.

Claessens, S., Demirgüç-Kunt, A., \& Huizinga, H. (2001). How does foreign entry affect the domestic banking market? Journal of Banking \& Finance, 25, 891-911.

Daily, C., \& Dalton, D. (1992). The relationship between governance structure and corporate performance in entrepreneurial firms. Journal of Business Venturing, 7, 375-382.

Eisenberg, T., Sundgren, S., \& Wells, M. T. (1998). Larger board size and decreasing firm value in small firms. Journal of Financial Economics, 48(1998), 35-54.

Farrel, M. J. (1957). The measurement of profit efficiency. Journal of the Royal Statistical Society, Series A, CXX(3), 253-290.

Gary, S. W., \& Gleason, A. (1999). Board structure, ownership and financial distress in banking firms. International Review of Economics and Finance, 8(3), 281-292.

Godard, L. (2001). La taille du conseil d'administration: déterminants et impact sur la performance. Cahier du FARGO n 1010702 , Juillet 2001.

Griffith, J. M., \& Fogelberg, L. (2000). Control and bank performance. Journal of Financial and Strategic Decision, 13(3), 63-69.

Hermalin, B. E., \& Weisbach, M. S. (2003). Boards of directors as an endogenous determined institution: a survey of economic literatures. Federal Reserve Bank of New York, Economic policy Review, 9(1), 7-26.

Hirschey, M. (1999). Managerial equity ownership and bank performance: entrenchment or size effects? Economics Letters, 64(2), 209-213.

Jensen, M. C. (1993). The modern industrial revolution, exit and the failure of internal control systems. Journal of Finance, 48(3), 831-880.

Jensen, M., \& Meckling, W. (1976). Theory of the firm: managerial behavior, agency costs and ownership structure. Journal of Financial Economics, 3(4), 305-360.

Johonsen, \& Scholes. (1997). Exploring corporate strategy: test and essay. New York: Prentice Hall.

Koh, P. T., \& Soon, L. C. (2004). Corporate governance of bank in Asia: country paper Malaysia. Tokyo Japan: Asian Development Bank Institute.

Kolsi, M. \& Ghorbel, H. (2011). Effet des mécanismes de gouvernance sur la performance financière et boursière : Cas des entreprises canadiennes. hal.archives-ouvertes.fr.

La Porta, R., Lopez-de-Silanes, F., \& Shleifer, A. (2002). Government ownership of commercial banks. Journal of Finance, 57, 265-301.

Lang, L. H., \& So, R. W. (2002). Bank ownership structure and economic performance. Chinese University of Hong Kong mimeo.

Leightner, J. E., \& Lovell, C. A. K. (1998). The impact of finance liberalization on the performance of Thai banks. Journal of Economics and Business, 50(2), 115-131.

Louizi, A. (2007). Les pratiques de gouvernance et la performance des entreprises Françaises. XVIème Conférence Internationale de Management Stratégique, Montréal, 6-9 Juin 2007.

Mejdoub, I. (2008). Mécanismes de gouvernance et performance financière des entreprises : un état de l'art. 7ème Colloque International de la Recherche en Sciences de Gestion. Hôtel Le Royal, Hammamet les 13, 14 \& 15 Mars 2008.

Miller, \& Noulas. (1996). The technical efficiency of large bank production. Journal Banking and Finance, 20, 495-509.

Morck, R., Shleifer, A., \& Vishny, R. W. (1988). Alternative mechanisms for corporate control. American Economic Review, 79(4), 842-852.

Oxelheim, I., \& Randy, T. (2003). The impact of foreign board membership on firm value. Journal of Banking \& Finance, 27(12), 2369-2392.

Paquerot, M. (1997). Stratégies d'enracinement des dirigeants, performance de la firme et structures de contrôle. Le gouvernement des entreprises : théories et faits, partie 1, chap.4, 105-138, Ed Economica.

Pi, L., \& Timme, S. G. (1993). Corporate control and bank efficiency. Journal of Banking \& Finance, 17, $515-530$.

Seiford \& Thrall (1990). Developement in DEA : The Mathematical Programming Approach.

Spong, K., DeYoung, R., \& Sullivan, R. J. (1999). Who's minding the store? Motivating and monitoring hired managers at small, closely held commercial banks. Journal of Banking \& Finance, 25, 1209-1243.

Whidbee, D. A. (1997). Board composition and control of shareholder voting rights in the banking industry. Financial Management, 26(4), 27-41.

Williams, J., \& Nguyen, N. (2005). Financial liberalization, crisis and restructuring: a comparative study of bank performance and bank governance in south East Asia. Journal of Banking \& Finance, 29.

Williamson, O. E. (1985). The economic institutions of capitalism (p. 1985). New York: The Free Press.

Yermack, D. (1996). Higher market valuation of companies with small board of directors. Journal of Financial Economics, 40, 185-211. 